\title{
Factors Associated with Leguminous Green Manure Incorporation and Fusarium Wilt Suppression in Watermelon
}

J. Himmelstein, Department of Plant Science and Landscape Architecture, University of Maryland, College Park 20742; J. E. Maul, United States Department of Agriculture-Agricultural Research Service, Beltsville, MD 20705; Y. Balci, Department of Plant Science and Landscape Architecture, University of Maryland; and K. L. Everts, Department of Plant Science and Landscape Architecture, University of Maryland, and University of Delaware, Georgetown 19947

\begin{abstract}
Himmelstein, J., Maul, J. E., Balci, Y., and Everts, K. L. 2016. Factors associated with leguminous green manure incorporation and Fusarium wilt suppression in watermelon. Plant Dis. 100:1910-1920.

Fall-planted Vicia villosa or Trifolium incarnatum cover crops, incorporated in spring as a green manure, can suppress Fusarium wilt (Fusarium oxysporum f. sp. niveum) of watermelon. During cover crop growth, termination, and incorporation into the soil, many factors such as arbuscular mycorrhizae colonization, leachate, and soil respiration differ. How these cover-crop-associated factors affect Fusarium wilt suppression is not fully understood. Experiments were conducted to evaluate how leachate, soil respiration, and other green-manure-associated changes affected Fusarium wilt suppression, and to evaluate the efficacy of the biocontrol product Actinovate AG (Streptomyces lydicus WYEC 108). General and specific suppression was examined in the field by assessing the effects of cover crop green manures $(V$. villosa, $T$. incarnatum, Secale cereale, and Brassica juncea) on soil respiration, presence of $F$. oxysporum spp., and arbuscular mycorrhizal colonization of watermelon. Cover crop treatments $V$. villosa, T. incarnatum, and $S$. cereale and no cover crop were evaluated both alone and in combination with Actinovate AG in the greenhouse. Additionally, in vitro experiments were conducted to measure the effects of cover crop leachate on the mycelial growth rates

of $F$. oxysporum f. sp. niveum race 1 and Trichoderma harzianum. Soil microbial respiration was significantly elevated in V. villos $a$ and Trifolium incarnatum treatments both preceding and following green manure incorporation, and was significantly negatively correlated with Fusarium wilt, suggesting that microbial activity was higher under the legumes, indicative of general suppression. Parallel to this, in vitro growth rates of $F$. oxysporum f. sp. niveum and Trichoderma harzianum on $V$. villosa leachate amended media were 66 and $213 \%$ greater, respectively, than on nonamended plates. The $F$. oxysporum spp. population (based on CFU and not differentiated into formae specialis or races) significantly increased in V. villosa-amended field plots. Additionally, the percentage of watermelon roots colonized by arbuscular mycorrhizae following $V$. villosa and Trifolium incarnatum green manures was significantly higher than in watermelon following bare ground (58 and $44 \%$ higher, respectively). In greenhouse trials where cover crops were amended to soil, Actinovate AG did not consistently reduce Fusarium wilt. Both general and specific disease suppression play a role in reducing Fusarium wilt on watermelon.
\end{abstract}

Watermelon (Citrullus lanatus (Thumb.) Matsum \& Nakai) is a major fresh-market vegetable grown in Maryland and Delaware (McCann et al. 2007). Production over the years has shifted from diploid (seeded) to triploid (seedless) watermelon (Lucier and BiingHwan 2001). Currently, triploid watermelon cultivars lack resistance to all races of Fusarium oxysporum f. sp. niveum W. C. Snyder \& H. N. Hansen, which causes Fusarium wilt (Everts and Hochmuth 2011; Everts and Zhou 2010). This is problematic because $F$. oxysporum f. sp. niveum is widespread on the eastern shore of Maryland and in Delaware (Zhou and Everts 2003) and management options other than resistant cultivars, including long crop rotations, soil solarization, elevation of soil $\mathrm{pH}$, and chemical fumigants (Eshel et al. 2000; Jones et al. 1976; Zitter et al. 1996), are available but vary in both cost and effectiveness. Methyl bromide was previously used as a soil fumigant in watermelon fields; however, more recently, less effective soil fumigants such as metam sodium and 1,3-dichloropropene have been used (Ferguson and Yee 1997; Gullino et al. 2003). In addition, a few microbial antagonists of $F$. oxysporum $\mathrm{f}$. sp. niveum have been studied (Ling et al. 2011; Wu et al. 2009); however, no

Current address of J. Himmelstein: ACDI/VOCA, Washington, DC 20001.

Current address of Y. Balci: United States Department of Agriculture-Animal and Plant Health Inspection Service, Plant Protection and Quarantine, Riverdale, MD 20737.

Corresponding author: K. L. Everts; Email: keverts@umd.edu

Accepted for publication 5 May 2016.

http://dx.doi.org/10.1094/PDIS-08-15-0956-RE

(C) 2016 The American Phytopathological Society biocontrol product is widely used for management of Fusarium wilt of watermelon and the small number of products that are available have not been extensively evaluated. The biocontrol product Actinovate AG (Natural Industries, Inc., Houston), which contains the active ingredient Streptomyces lydicus WYEC 108, is one example. Actinovate AG has reduced the incidence or severity of several plant diseases, such as Fusarium wilt of cyclamen caused by F. oxysporum f. sp. cyclaminis, dollar spot caused by Sclerotinia homoeocarpa, and surface rot of sweet potato caused by Fusarium spp., and is labeled for use on Fusarium wilt of watermelon (Elmer and McGovern 2004; Henn and Burdine 2010; Tomaso-Peterson and Perry 2007).

Cultural practices such as the use of cover crops may also reduce watermelon Fusarium wilt severity. Recent studies have focused on the incorporation of the cover crops Vicia villosa and Trifolium incarnatum as a green manure, which suppressed the severity of Fusarium wilt of watermelon by up to 69 and $21 \%$, respectively (Himmelstein et al. 2014; Keinath et al. 2010; Zhou and Everts 2004, 2007; Zhou et al. 2002). Green manure incorporation changes the soil environment in many ways; for example, by producing leachate, increasing soil respiration, and increasing the abundance of arbuscular mycorrhizae following mycorrhizal colonized cover crops, and so on (Galvez et al. 1995; Grünwald et al. 2000). How these green-manuremediated changes individually relate to Fusarium wilt suppression in subsequent watermelon crops is not known.

Disease suppression can be categorized as general or specific. General suppression is defined as suppression that arises from the overall activity of soil biota and influences a wide range of soilborne pathogens (van Os and van Ginkel 2001; Weller et al. 2002). Specific suppression occurs when the activity of a specific antagonist or a defined group of microorganisms suppresses disease (van Os and van Ginkel 2001; Weller et al. 2002). Examples of specific suppression 
induced by a cover crop green manure include the fungitoxic effects of Brassica spp. leachates on a range of plant pathogens (Angus et al. 1994; Kirkegaard and Sarwar 1998). Individual organisms also may induce specific suppression. For example, nonpathogenic $F$. oxysporum spp. may play a role in Fusarium-wilt-suppressive soils (Alabouvette et al. 1993). The mycoparasite Trichoderma harzianum is used to induce specific suppression, and can proliferate quickly in the rhizosphere and effectively compete for nutrients (Howell 2003; Sivan and Chet 1989). Commercial formulations of T. harzianum such as Rootshield (Bioworks, Inc., Victor, NY) are incorporated into the soil to suppress specific plant pathogens such as Pythium aphanidermatum or F. oxysporum f. sp. ciceris (Dubey et al. 2007; Howell 2003; Sivan and Chet 1989).

Decreases in plant disease due to arbuscular mycorrhizal colonization might also be considered a form of specific suppression, depending on the pathosystem (Cordier et al. 1998; Kaya et al. 2003; Scheffknecht et al. 2006; Tobar et al. 1994). Cover crops can influence the quantity and composition of arbuscular mycorrhizal soil populations both during and after cover crop rotation (Buyer et al. 2010; Galvez et al. 1995; Rutto et al. 2003). V. villosa cover crop amendments increased mycorrhizal populations in the rhizosphere of a subsequent tomato crop (Buyer et al. 2010), as well as mycorrhizal colonization of peach seedlings (Galvez et al. 1995; Rutto et al. 2003). Little is known about the potential role that arbuscular mycorrhiza play in $V$. villosa disease suppression of Fusarium wilt. However, a recent study found that enhanced arbuscular mycorrhizal colonization of watermelon roots significantly reduced Fusarium wilt (Ren et al. 2015).

Substrate respiration and microbial biomass are often cited as key factors for measuring the likelihood of general disease suppression (Alabouvette et al. 1985; Bonanomi et al. 2010; Tsuneo 1991). Soil biota respiration rates (evolution of $\mathrm{CO}_{2}$ from soils) from fields naturally suppressive to Fusarium wilt of watermelon have been compared with that of nonsuppressive soils (Alabouvette et al. 1985). The suppressive soils had respiration rates that were two- to fourfold that of nonsuppressive soils and it was proposed that the mechanism of the suppression was excessive competition for nutrients, a form of general suppression.

During cover crop growth and subsequent incorporation into the soil as a green manure, increased organic matter, increased crop leachates, and changes to the microbiota occur, which may specifically affect $F$. oxysporum f. sp. niveum. Alternatively, enhancement of overall microbial biomass and nutrient competition may promote general suppression. We hypothesized that evaluation of these covercrop-mediated changes and their relationship to Fusarium wilt suppression would increase our understanding of whether suppression was general or specific. We also examined the efficacy of the biocontrol product Actinovate AG in Fusarium wilt management. This was done by (i) investigating the effects of $V$. villosa, Trifolium incarnatum, Secale cereale, and Brassica juncea green manure amendments on the rate of soil microbial respiration, changes in F. oxysporum spp. soil population size, and percent arbuscular mycorrhizal colonization of watermelon roots in fields where $V$. villosa and $T$. incarnatum disease suppression were observed; (ii) comparing the efficacy of Actinovate AG alone and in combination with three different cover crop amendments under controlled greenhouse conditions; (iii) evaluating the in vitro effect of $V$. villosa, T. incarnatum, and $S$. cereale leachate on the mycelial growth of $F$. oxysporum $\mathrm{f}$. sp. niveum and Trichoderma harzianum; and (iv) assessing in vitro inhibitory effects of S. lydicus on $F$. oxysporum f. sp. niveum.

\section{Materials and Methods}

Fungal isolates. F. oxysporum f. sp. niveum race 1 (isolate F-030-1) from the eastern shore of Maryland was used for in vitro assays and laboratory and field trials (Zhou and Everts 2003). T. harzianum (isolate GJS-00-150) obtained from Beltsville Agricultural Research Center was utilized for in vitro assays (Küçük and Kıvanç 2003).

Field experiments. Field experiments were conducted in Maryland and Delaware from 2009 to 2011 to evaluate the impact of cover crops on Fusarium wilt and yield. The experimental methodology as well as impact of these cover crops on Fusarium wilt suppression have been reported previously (Himmelstein et al. 2014). Trials were established at the United States Department of Agriculture-Beltsville Agricultural Research Center (USDA-BARC) in 2009 and 2010; the University of Maryland Lower Eastern Shore Research and Education Center in Salisbury (UM-LESREC) in 2009, 2010, and 2011; and the University of Delaware Carvel Research and Education Center in Georgetown (UD-REC) in 2011.

Each field was set up as a completely randomized split plot block design, with cover crops as the main plot treatments and Actinovate AG application as the subplot treatments (Table 1). V. villosa, Trifolium incarnatum, S. cereale, B. juncea, and bare ground were the main plot treatments; however, not all cover crop treatments were planted for every field trial (Table 1). An additional subplot treatment included inoculation with $F$. oxysporum $\mathrm{f}$. sp. niveum (USDA-BARC 2009 and 2010 and UM-LESREC 2009), unless the field was already infested with $F$. oxysporum f. sp. niveum (Table1). In inoculated fields, the subplots were (i) $F$. oxysporum f. sp. niveum inoculation + Actinovate AG application, (ii) $F$. oxysporum f. sp. niveum inoculation, and (iii) a nontreated and noninoculated control. In the fields at UM-LESREC and UD-REC naturally infested by $F$. oxysporum f. sp. niveum, the subplots treatments were (i) Actinovate AG application or (ii) no Actinovate AG.

Cover crops were drill seeded in early fall and, in the early spring, killed with paraquat (Gramoxone Extra $2.5 \mathrm{SC}$ at $1.2 \mathrm{~kg}$ a.i./ha or 1.75 liter/ha) 7 days before being disked into the soil with a tractormounted rototiller to a depth of approximately 10 to $20 \mathrm{~cm}$. Control plots were also cultivated with this method (Table 1).

Soil respiration. Soil respiration was measured in plots infested with $F$. oxysporum f. sp. niveum and amended with cover crop or bare ground using an EGM-4 gas analyzer with an SRC-1 chamber from PP Systems (Amesbury, MA) (Korhonen et al. 2009). The EGM-4 gas analyzer has a closed chamber that measures $\mathrm{CO}_{2}$ flux within the chamber at a flow rate of $350 \mathrm{ml} / \mathrm{min}$. The beveled collar seals were placed in the plots at least $24 \mathrm{~h}$ prior to measurements. Collars were pushed $4 \mathrm{~cm}$ into the soil and approximately $7 \mathrm{~cm}$ of the collars remained above the soil line. Respiration was measured from at least three collars placed randomly in each plot and then averaged per a plot. Treatments in three to six replicates were measured in each trial ( $n=45$ to 90$)$. A soil temperature sensor (PP Systems TRP-2 temperature probe) was connected to the EGM-4 data logger to record plot soil temperature while soil respiration data were collected.

Soil respiration measurements were recorded for five field trials: two at USDA-BARC, two at UM-LESREC, and one at UD-REC. The first field trial was at USDA-BARC in 2009, where respiration was measured before tillage and during watermelon production. $\mathrm{Be}$ cause the largest magnitude of treatment differences for elevations in soil respiration occurred following tillage in these trials, in subsequent trials, $\mathrm{CO}_{2}$ flux was primarily recorded following tillage.

Soil dilutions. The effect of cover crop treatment on the general population of $F$. oxysporum spp. in the soil ( $F$. oxysporum $\mathrm{f}$. sp. niveum was not differentiated from nonpathogenic $F$. oxysporum) was evaluated in 2010 and 2011 (two locations each year) by soil dilution onto selective media. Soil cores were collected once toward the end of the growing season from every plot at each location $(n=$ 60/field location; Table 1) in 2010. The following year, a baseline sample was collected in March (Table 1), when cover crop growth was minimal. Subsequent samples were collected again near the end of the growing season (Table 1). One soil core was collected from three locations within each subplot, the three cores were thoroughly mixed, and a 5-g subsample (dry weight equivalent) was placed in $45 \mathrm{ml}$ of autoclaved $0.1 \%$ water agar. This solution was mixed on a rotary shaker at $150 \mathrm{rpm}$ and vortexed, and $1 \mathrm{ml}$ of the soil suspension was spread evenly onto plates of Komada's media (Komada 1975) for a 1:10 soil dilution. Additionally, a 1-ml aliquot of the suspension was transferred to test tubes with $9 \mathrm{ml}$ of $0.1 \%$ autoclaved water agar and vortexed, and $1 \mathrm{ml}$ of the resulting suspension was added to Komada's media plates for a 1:100 soil dilution (Zhou and Everts 2004). The resulting colonies of F. oxysporum spp., based on colony pigmentation and morphology, were counted 5 days after 
plating. The CFU per gram were adjusted to dry weight equivalent prior to statistical analysis.

Arbuscular mycorrhizae. In summer 2010, watermelon roots were sampled from a field experiment at UM-LESREC and USDABARC. An entire watermelon plant, with its root system intact, was gently uprooted from each subplot 3 weeks after the watermelon were transplanted to the field. Two plants per plot were sampled from four replicates at UM-LESREC. One plant per plot was sampled from three replicates at USDA-BARC. Roots were scanned using WinRhizo Pro 2004b software (Regent Instruments Inc., Quebec, QC, Canada) to obtain root total area and diameter.

A protocol by Morton (2003) was used to evaluate the arbuscular mycorrhizal colonization. First, roots were stained with $0.05 \%$ trypan blue in lactophenol. Fine roots were washed at least three times, placed in plastic cassettes, and cleared in hot $10 \% \mathrm{KOH}$ for $10 \mathrm{~min}$. The roots were washed again in water and the cassettes immersed in $2 \% \mathrm{HCL}$ for $20 \mathrm{~min}$, rinsed again, then soaked in trypan blue for a minimum of $12 \mathrm{~h}$ before they were stored in a 2:1 water-glycerin mix. Thin feeder roots (25 10-mm root segments from each plant) were examined under a light microscope for mycorrhizal infection (Matsubara et al. 2001). An infected node was defined as a 10-mm root segment where the presence of an arbuscule had been detected (EgertonWarburton and Allen 2000; Newsham et al. 1995). Because only fine roots were examined for arbuscular mycorrhizal colonization, the equation for percent arbuscular mycorrhizal was adjusted to include only the fine roots, identified by the WinRhizo software as roots $<0.5 \mathrm{~cm}$ in diameter. Therefore, the percentage of arbuscular mycorrhizal infection was defined as (number of nodes infected/ number of nodes observed) $\times 100$ relative to the percentage of roots $<0.5 \mathrm{~cm}$ in diameter.

Greenhouse experiments. The capacity of Streptomyces lydicus WYEC 108, the active ingredient of the biological control product Actinovate AG, to colonize watermelon roots or the rhizosphere in natural field soil and the biocontrol product's ability to suppress disease when used alone or in combination with three different green manure amendments was evaluated in two greenhouse pot trials in fall 2011, the first at UM-LESREC and the second at UD-REC.

The experiment was arranged as a completely randomized factorial design with nine replicates per treatment $(n=216)$. Treatments were soils amended with cover crop residue or no residue and $F$. oxysporum f. sp. niveum or Actinovate AG application. A Fort Mott loamy sand field soil from Salisbury, MD (homogenized with a soil mixer) was used in both experiments.

Watermelon 'Sugar Heart' was seeded in 128-cell trays and grown in Sun Gro Redi-earth Plug and Seedling Mix (Sun Gro Horticulture, Bellevue, WA) in ambient greenhouse temperatures $\left(20\right.$ to $\left.31^{\circ} \mathrm{C}\right)$ for two-and-a-half weeks. Actinovate AG was suspended in water and applied to 10-day-old seedlings at $0.08 \mathrm{~g}$ per 0.09 liter of $\mathrm{H}_{2} \mathrm{O} / \mathrm{m}^{2}$ ( $0.012 \mathrm{~g}$ per $13.24 \mathrm{ml}$ of $\mathrm{H}_{2} \mathrm{O}$ per $0.14-\mathrm{m}^{2}$ tray). Seedlings were gently repotted 7 days after the first Actinovate AG application and an Actinovate AG soil drench was applied to the $29-\mathrm{cm}^{2}$ pots at $0.06 \mathrm{~g}$ per 0.09 liter of $\mathrm{H}_{2} \mathrm{O} / \mathrm{m}^{2}\left(0.017 \mathrm{~g}\right.$ per $26.34 \mathrm{ml}$ of $\mathrm{H}_{2} \mathrm{O}$ per $29 \mathrm{~cm}^{2} /$ pot) the same day.

Pathogen inoculum of $F$. oxysporum f. sp. niveum was prepared by transferring isolate F-030-1 growing on Komada's media into a liquid mineral salts medium (Netzer 1976; Zhou and Everts 2006). The culture was incubated on an orbital shaker at $128 \mathrm{rpm}$ at room temperature for approximately 2 weeks before filtering through eight layers of cheesecloth. The spore suspension was amended to the soil to attain a 2,500 CFU/g concentration, mixed thoroughly, then incubated in plastic bags with filtered air exchange at room temperature for a week-and-a-half to allow for the formation of chlamydospores (Zhou and Everts 2004).

Cover crop biomass was incorporated 10 days after $F$. oxysporum f. sp. niveum inoculation and, at the same time, also into noninfested soil. Cover crop treatments were soil amendments of (i) $V$. villosa, (ii) Secale cereale, (iii) T. incarnatum, and (iv) no cover crop amendment (bare soil). The cover crop biomass was collected from fields

Table 1. Management and design of field experiments to evaluate tilled cover crop and Actinovate AG biocontrol application on Fusarium wilt severity and watermelon yield for six field experiments in Maryland and Delawarew

\begin{tabular}{|c|c|c|c|c|c|c|}
\hline \multirow[b]{2}{*}{ Treatment } & \multicolumn{6}{|c|}{ Location, year ${ }^{x}$} \\
\hline & $\begin{array}{l}\text { USDA-BARC } 2009 \\
\end{array}$ & USDA-BARC 2010 & UM-LESREC 2009 & UM-LESREC 2010 & UM-LESREC 2011 & UD-REC 2011 \\
\hline \multirow[t]{5}{*}{ Main plot } & Vicia villosa & V. villosa & V. villosa & V. villosa & V. villosa & V. villosa \\
\hline & Trifolium incarnatum & T. incarnatum & Secale cereale & T. incarnatum & T. incarnatum & T. incarnatum \\
\hline & Secale cereale & Brassica juncea & Bare ground & B. juncea & B. juncea & B. juncea \\
\hline & Bare ground & S. cereale & $\ldots$ & S. cereale & S. cereale & S. cereale \\
\hline & $\ldots$ & Bare ground & $\ldots$ & Bare ground & Bare ground & Bare ground \\
\hline \multirow[t]{2}{*}{ Subplot } & FON & FON & FON & Actinovate & Actinovate & Actinovate \\
\hline & $\begin{array}{l}\text { FON + Actinovate, } \\
\text { No FON }\end{array}$ & $\begin{array}{l}\text { FON + Actinovate, } \\
\text { No FON }\end{array}$ & $\begin{array}{l}\text { FON + Actinovate, } \\
\text { No FON }\end{array}$ & No Actinovate & No Actinovate & No Actinovate \\
\hline \multicolumn{7}{|l|}{ Cover crop } \\
\hline \multicolumn{7}{|c|}{ Seeding rates $(\mathrm{kg} / \mathrm{ha})$} \\
\hline V. villosa & 44.83 & 44.83 & 50.44 & 50.44 & 50.44 & 50.44 \\
\hline T. incarnatum & 28.02 & 28.02 & & 11.21 & 11.21 & 11.21 \\
\hline S. cereale & 134.50 & 134.50 & 134.50 & 125.54 & 125.54 & 125.54 \\
\hline B. juncea & $\ldots$ & 6.73 & $\ldots$ & 11.21 & 11.21 & 11.21 \\
\hline \multirow{2}{*}{ Seeding dates } & 24 September 2008 & 22 September 2009 & 16 October 2008 & 25 September 2009 & 15 October 2010 & 25 October 2010 \\
\hline & $\ldots$ & $\ldots$ & $\ldots$ & & 9 March $2011^{y}$ & 15 March 2011 \\
\hline Tillage & 23 May 2009 & 23 May 2010 & 15 May 2009 & 24 May 2010 & 19 May 2011 & 25 May 2011 \\
\hline \multicolumn{7}{|l|}{ Application dates $\mathrm{z}$} \\
\hline Foliar & 3 June 2009 & 16 June 2010 & 2 June 2009 & 8 June 2010 & 20 May 2011 & 26 May 2011 \\
\hline Soil drench & 29 June 2009 & 29 June 2010 & 29 June 2009 & 15 June 2010 & 3 June 2011 & 7 June 2010 \\
\hline Transplanting date & 17 June 2009 & 18 June 2010 & 19 June 2009 & 12 June 2010 & 3 June 2011 & 7 June 2011 \\
\hline \multirow[t]{2}{*}{ Soil dilution date } & $\ldots$ & 23 August 2010 & $\ldots$ & 20 July 2010 & 17 March 2011 & 17 March 2011 \\
\hline & $\ldots$ & $\ldots$ & $\ldots$ & $\ldots$ & 20 May 2011 & 22 June 2011 \\
\hline
\end{tabular}

\footnotetext{
${ }^{\mathrm{w}}$ Actinovate AG (Streptomyces lydicusWYEC108) is a biocontrol product (Natural Industries Inc.) which is labeled for management of Fusarium wilt of watermelon.

${ }^{x}$ UM-LESREC = University of Maryland Lower Eastern Shore Research and Education Center, located in Salisbury, MD; USDA-BARC = United States Department of Agriculture Beltsville Agricultural Research Center, located in Beltsville, MD; UD-REC = University of Delaware's Carvel Research and Education Center, located in Georgetown, DE; and FON = Fusarium oxysporum f. sp. niveum.

y In 2011, cover crops were overseeded in the early spring to ensure that plots had sufficient cover crop biomass.

z Dates of Actinovate AG applications.
} 
at UM-LESREC and USDA-BARC in early spring (18 and 19 May 2011), dried in the greenhouse, then chopped into pieces approximately 4 to $6 \mathrm{~cm}$ long to represent rough tillage.

The $V$. villosa biomass was incorporated into the infested or noninfested soil at three different rates-2,722 kg/ha (1×), 3,685 kg/ha $(2 \times)$, and 5,670 kg/ha (3x) — to represent 2009 and 2010 average field level cover crop biomass at UM-LESREC, a median level, and USDA-BARC, respectively. T. incarnatum was incorporated into soils at $5,103 \mathrm{~kg} / \mathrm{ha}$ and $S$. cereale was incorporated at $3,969 \mathrm{~kg} / \mathrm{ha}$. Biomass was mixed into the soil by hand, watered, and allowed to decompose for 2 weeks. Amended soil was then transferred into sterilized plastic pots $\left(29 \mathrm{~cm}^{2}\right)$. A single Sugar Heart seedling was transplanted into each pot and greenhouse conditions were maintained at 20 to $31^{\circ} \mathrm{C}$. Plants were mechanically watered twice a day for $5 \mathrm{~min}$ at 7:30 A.M. and 3:00 P.M. at UM-LESREC and hand watered twice a day at UD-REC.

Six treatment replicates were evaluated for wilt severity and vine length $(n=144)$. Wilt severity was evaluated weekly for 6 weeks on a scale of 0 to 3 , where $0=0,1=1$ to $33,2=34$ to 63 , and $3=64$ to $100 \%$ wilted foliage. Watermelon plants that died of wilt were plated on Komada's media to confirm the presence of $F$. oxysporum based on pigmentation and colony morphology. Vine length, which was the length of the longest watermelon vine from the crown of the plant to the vine tip, was measured for each pot weekly for 6 weeks. Plants from three treatment replicates $(n=72)$ were destructively harvested 2 weeks after watermelon plants had been transferred to pots to determine whether Streptomyces lydicus was present in the rhizosphere. Seminal roots of watermelon plants were cut into three $3-\mathrm{cm}$-long root sections and vortexed in $5 \mathrm{ml}$ of sterile distilled water for $5 \mathrm{~min}$, and the water was serially diluted onto sporulation agar (SPA) (Yuan and Crawford 1995).

In vitro assays. Leachate assays. Leachate of $V$. villosa, $T$. incarnatum, and Secale cereale was collected by placing cover crop biomass below a sprinkler system that emitted a similar amount of water (approximately $3 \mathrm{~mm}$ ) as an average rainfall event on the eastern shore of Maryland in spring. Fresh aboveground biomass of $V$. villosa was collected in late spring at UM-LESREC, $S$. cereale biomass from the University of Maryland Wye Research and Education Center, and T. incarnatum biomass from the USDA-BARC. Cover crop biomass concentrations for leachate production were based on the average aboveground cover crop biomass found in previous field trials at UM-LESREC and USDA-BARC. These concentrations were $T$. incarnatum at $5,103 \mathrm{~kg} / \mathrm{ha}, S$. cereal at 3,969 kg/ha, and $V$. villosa at $2,834 \mathrm{~kg} / \mathrm{ha}$. For leachate collection, biomass concentrations were doubled for $S$. cereale and $T$. incarnatum and quadrupled for $V$. villosa to account for the subsequent dilutions necessary for producing leachate-amended potato dextrose agar (PDA; Difco, Franklin Lakes, NJ), so that final treatment amendments would be representative of field conditions. Cover crops were cut into 5- to 7-cm length fragments to mimic rough tillage and placed on a screen $\left(8,788 \mathrm{~cm}^{2}\right)$ atop a collection bin and beneath overhead sprinklers. Prior to leachate collection, the bin used was placed below the sprinklers to determine the amount of water that was emitted from the overhead sprinklers every $5 \mathrm{~min}$ so that the appropriate ratio of cover crop biomass to water could be calculated. For each liter of water, $0.53 \mathrm{~kg}$ of $S$. cereale, $1.22 \mathrm{~kg}$ of $T$. incarnatum, and $2.45 \mathrm{~kg}$ of $V$. villosa was placed atop the screen. The water that filtered through the cover crop biomass was the leachate used for the plate assays.

The leachate was incorporated into the PDA media as follows. PDA was prepared using half the volume of distilled water specified in the recipe and autoclaved. After media had cooled to approximately $50^{\circ} \mathrm{C}$, it was brought up to volume with the $2 \times$ leachate (or, in the case of $V$. villosa, $4 \times)$. Streptomycin $(0.3 \mathrm{~g}$ per $1,000 \mathrm{ml})$ and oxgall $(0.5 \mathrm{~g}$ per $1,000 \mathrm{ml})$ were added to the media and homogenized. All leachate treatments were produced in this manner, except for the $V$. villosa $1 \times$ treatment, because the $V$. villosa leachate was collected at $4 \times$ the concentration so that $1 \times$ and $2 \times V$. villosa treatments could be evaluated. To produce the $V$. villosa $1 \times$ leachate, PDA was autoclaved with three-quarters volume of distilled water and brought up to full volume with the $V$. villosa $4 \times$ leachate, the same antibiotics were added, and the solution was stirred prior to pouring plates. Nonamended PDA was the control. All media treatments were adjusted to a $\mathrm{pH} 3.5$ or 6 with lactic acid. Moderate and low $\mathrm{pH}$ levels were chosen because the region is characterized by slightly acidic soils and Fusarium wilt is favored by low $\mathrm{pH}$ (Jones et al. 1976; Zitter et al. 1996).

Isolate F-030-1 of $F$. oxysporum f. sp. niveum was transferred to PDA plates and grown at $28^{\circ} \mathrm{C}$ for approximately 10 days and Trichoderma harzianum for 4 days before transferring 5-mm plugs from the edges of the colony to the center of all leachate-amended media plates and control plates. Following inoculation, plates were incubated at $25^{\circ} \mathrm{C}$. Each experiment was conducted twice. In all, 10 replicate plates per treatment combination (cover crop leachate $+\mathrm{pH}$ level + fungus) were used in the first assay and 14 replicate plates per treatment combination in the second assay.

In the first assay, fungal radial growth was measured at 24-h intervals. In the second assay, radial growth was measured every $6 \mathrm{~h}$ for the initial 10 readings and then every $24 \mathrm{~h}$ until the fungus reached the edge of the control plates or significant advances in growth had ceased (Larkin and Griffin 2007). At this point, 5-mm agar plugs were taken from the periphery of fungal growth and placed on nonamended PDA plates to test the viability of the fungi (Al-Reza et al. 2010; Yuan and Crawford 1995). The morphology of the fungi along the border of the colonies was examined with a dissecting and compound microscope to detect any unusual changes in morphology (abnormal branching or swollen tips of hyphae) or hyphal tip lysis (Yuan and Crawford 1995).

Streptomyces lydicus assays. To determine the inhibition of $F$. oxysporum f. sp. niveum mycelial growth in the presence of Streptomyces lydicus, PDA was inoculated with $S$. lydicus that was isolated directly from the Actinovate AG product, the S. lydicus WYEC 108 isolate obtained directly from Natural Industries, or not inoculated. Working cultures from the Actinovate AG product were obtained by pipetting $60 \mathrm{ml}$ of Actinovate $\mathrm{AG}$ at a concentration of $6.1 \mathrm{~g}$ per 10 liters onto SPA plates (Leupold 1970). The plates were incubated at $30^{\circ} \mathrm{C}$ for approximately 10 days so that the $S$. lydicus sporulation was profuse. The $S$. lydicus isolates were uniformly streaked onto PDA plates (previously adjusted to $\mathrm{pH} 3.5$ ) from the edge of the working plate to the quarter-radius line and grown for 5 days at $30^{\circ} \mathrm{C}$ (Getha et al. 2005; Yuan and Crawford 1995). A 5-mm-diameter agar plug of $F$. oxysporum f. sp. niveum mycelium was then placed on the opposite side of the plate, directly adjacent to the quarter-radius line. Nonstreaked SPA plates with $F$. oxysporum $\mathrm{f}$. sp. niveum plugs placed at the quarter-radius line served as a control. The plates were incubated at $30^{\circ} \mathrm{C}$ and assessed for growth inhibition at 24-h intervals for 12 days. The experiment was conducted twice. The viability and morphology of the $F$. oxysporum $\mathrm{f}$. sp. niveum was evaluated after mycelia reached the border of the control plates with the same methodology described above.

Statistical analyses. A correlation analysis was performed for wilt severity and respiration. The MIXED procedure was used and means were separated at a $P \leq 0.05$ and by using Pearson's correlation analysis. Analysis was performed for UM-LESREC and UD-REC in 2011, the years and locations where legume cover crop suppression of Fusarium wilt occurred and where cover crop treatment effects on respiration and wilt severity were significant.

Data were analyzed using the MIXED procedure with the Statistical Analysis System (version 9.2; SAS Institute, Cary, NC). Fixed effects were cover crop and cover crop concentration (leachate assays) and S. lydicus, and replication and replication interactions were treated as random effects (Littell et al. 1998). Ordinal data (Fusarium wilt greenhouse trial) was back transformed to the midpoint of the associated severity range prior to conducting the analysis of variance using SPSS Statistics 23. Means of treatment effects were separated using a Fisher's protected least significant difference test at $\alpha=0.05$.

\section{Results}

Field experiments. Fusarium wilt of watermelon was significantly suppressed (as much as $21 \%$ ) by V. villosa and Trifolium 
incarnatum in these field experiments (Himmelstein et al. 2014). However, the efficacy of Actinovate AG in managing Fusarium wilt was minimal and inconsistent. Therefore, additional evaluation of soil microbial respiration, populations of $F$. oxysporum spp. (not differentiated into races), and the percent colonization of watermelon roots were conducted in the fields where the disease suppression was observed.

Soil respiration. Significant differences in soil respiration among plots amended with different cover crop treatments occurred prior to tillage and immediately following tillage but not later (Table 2). As compared with other green manure treatments or bare ground, $V$. villosa-amended plots had significantly higher rates of $\mathrm{CO}_{2}$ respiration 3 weeks prior to tillage at USDA-BARC in 2010 (33 and $137 \%$, respectively), 1 day following tillage at UM-LESREC in 2010 (33 and $111 \%$, respectively), 1 day following tillage at UM-LESREC in 2011 (57 and 390\%, respectively), and 2 days following tillage at UD-REC in 2011 (42 and 161\% respectively; Table 2). At four of the five locations where $\mathrm{CO}_{2}$ was measured, respiration rates were significantly higher in $V$. villosa-amended plots compared with all other cover crop and bare ground plots. Additionally, respiration in $V$. villosa-amended plots was significantly higher (three times) than that of bare ground at USDA-BARC in 2010, 1 day after tillage (Table 2).

Respiration rates in T. incarnatum-amended plots were significantly higher (one to three times) than in nonamended plots for at least one or more measurement dates in four of the five field trials (Table 2). Plots amended with $T$. incarnatum had significantly higher rates of $\mathrm{CO}_{2}$ respiration 5 days prior to tillage (35\% higher) and 5 days after tillage ( $70 \%$ higher) compared with all other treatments at USDA-BARC in 2009. For measurements taken 3 weeks and 10 days prior to tillage at USDA-BARC in 2010, as well as 1 day after tillage, the flux of $\mathrm{CO}_{2}$ was higher $(68,30$, and $42 \%$, respectively) in $T$. incarnatum-amended plots compared with bare ground. Respiration was significantly higher (50 to $213 \%$ ) in T. incarnatumamended plots than in bare ground plots for all measurements taken at UM-LESREC in 2010 and 2011.
For one or more dates in all five field trials, B. juncea- and Secale cereale-amended plots had rates of respiration that were significantly lower than the legume amended plots (as much as four times). Respiration was never significantly higher in $B$. juncea- or $S$. cerealeamended plots compared with that of legume plots. The respiration in B. juncea-amended plots was significantly higher than bare ground respiration for three sampling dates at USDA-BARC in 2010, and was significantly lower than all other green-manure-amended plots for both measurements taken at UM-LESREC in 2011 (Table 2). Although soil respiration measurements in $S$. cereale-amended plots were significantly higher than bare ground for three field trials, it was also significantly lower than all other green-manure-amended and nonamended plots at UD-REC in 2011.

Respiration was negatively correlated with wilt severity at UMLESREC in 2011 and UD-REC in 2011. Wilt severity, measured 6 weeks after watermelon were transplanted into the field at UDREC in 2011, was negatively correlated with respiration, the morning after cover crop tillage ( $r=-0.39, P=0.0328)$. The area under the disease progress curve (AUDPC) $(r=-0.64, P=0.0107)$ and wilt severity recorded 4 weeks $(r=-0.76, P=0.0010)$ and 5 weeks $(r=-0.61, P=0.0163)$ after transplanting at UM-LESREC in 2011 were significantly negatively correlated with respiration measured 1 day after tillage. At that same field site, all wilt severity measurements where significant cover crop treatment effects were observed-4 weeks $(r=-0.60, P=0.0004), 5$ weeks $(r=-0.64$, $P=0.0001), 6$ weeks $(r=-0.53, P=0.0025)$, and 7 weeks $(r=$ $-0.45, P=0.0118)$ after transplanting - as well as the AUDPC values $(r=-0.50, P=0.0053)$ were negatively correlated with respiration measured 2 days after cover crop incorporation. All of the Pearson's correlation coefficients were negative (data not shown), demonstrating that there is an inverse relationship between wilt severity and respiration. Overall, plots with a higher respiration rate had lower wilt severity ratings.

Soil dilutions. The CFU per gram of $F$. oxysporum spp. was significantly higher ( 53 to $408 \%$ higher) in $V$. villosa-amended plots compared with bare-ground treatments for two of the four field trials

Table 2. Soil surface $\mathrm{CO}_{2}$ flux values in watermelon field experiments before and after spring-incorporated cover crop treatments or bare ground (control)

\begin{tabular}{|c|c|c|c|c|c|c|c|}
\hline \multirow[b]{3}{*}{ Year, location ${ }^{y}$} & \multirow[b]{3}{*}{ Date $^{\mathrm{z}}$} & \multicolumn{5}{|c|}{$\mathrm{CO}_{2}$ flux $\left(\mu \mathrm{mol} \mathrm{m} \mathrm{m}^{-2} \mathrm{~s}^{-1}\right)^{\mathrm{x}}$} & \multirow[b]{3}{*}{$P>F$} \\
\hline & & \multicolumn{4}{|c|}{ Cover crop } & \multirow[b]{2}{*}{ Bare ground } & \\
\hline & & Vicia villosa & Trifolium incarnatum & Secale cereale & Brassica juncea & & \\
\hline \multicolumn{8}{|l|}{2009} \\
\hline \multirow[t]{6}{*}{ USDA-BARC } & 18 Маy* & $1.06 \mathrm{~b}$ & $1.43 \mathrm{a}$ & $0.89 \mathrm{~b}$ & $\ldots$ & $0.86 \mathrm{~b}$ & 0.0064 \\
\hline & 28 May & $2.40 \mathrm{~b}$ & $4.95 \mathrm{a}$ & $2.91 \mathrm{~b}$ & $\ldots$ & $2.56 \mathrm{~b}$ & 0.0062 \\
\hline & 9 June & 0.71 & 1.81 & 0.89 & $\ldots$ & 1.03 & 0.6974 \\
\hline & 11 June & 0.88 & 0.94 & 0.88 & $\ldots$ & 1.00 & 0.2593 \\
\hline & 10 July & 0.85 & 0.80 & - & $\ldots$ & 0.71 & 0.2056 \\
\hline & 3 August & 4.72 & 3.00 & 2.75 & $\ldots$ & 3.45 & 0.084 \\
\hline \multicolumn{8}{|l|}{2010} \\
\hline \multirow[t]{4}{*}{ USDA-BARC } & 30 April* & $0.97 \mathrm{a}$ & $0.69 \mathrm{~b}$ & $0.68 \mathrm{~b}$ & $0.73 \mathrm{~b}$ & $0.41 \mathrm{c}$ & 0.0007 \\
\hline & 13 Мау* & $0.91 \mathrm{ab}$ & $0.99 \mathrm{a}$ & $0.74 \mathrm{c}$ & $0.93 \mathrm{a}$ & $0.76 \mathrm{bc}$ & 0.0109 \\
\hline & 22 May* & 2.22 & 1.37 & 1.22 & 1.22 & 0.80 & 0.3786 \\
\hline & 24-May & $16.02 \mathrm{a}$ & $15.77 \mathrm{a}$ & $14.64 \mathrm{a}$ & $11.52 \mathrm{a}$ & $5.21 \mathrm{~b}$ & 0.0145 \\
\hline UM-LESREC & 25-May & $0.97 \mathrm{a}$ & $0.69 \mathrm{~b}$ & $0.68 \mathrm{~b}$ & $0.73 \mathrm{~b}$ & $0.46 \mathrm{c}$ & $<0.0001$ \\
\hline \multicolumn{8}{|l|}{2011} \\
\hline \multirow[t]{2}{*}{ UM-LESREC } & 20 May & $1.08 \mathrm{a}$ & $0.69 \mathrm{~b}$ & $0.49 \mathrm{~b}$ & $0.27 \mathrm{c}$ & $0.22 \mathrm{c}$ & $<0.0001$ \\
\hline & 21 May & $1.04 \mathrm{a}$ & $0.65 \mathrm{~b}$ & $0.59 \mathrm{~b}$ & $0.30 \mathrm{c}$ & $0.25 \mathrm{c}$ & $<0.0001$ \\
\hline \multirow[t]{3}{*}{ UD-REC } & 26 May & $0.87 \mathrm{a}$ & $0.50 \mathrm{~b}$ & $0.29 \mathrm{c}$ & $0.49 \mathrm{bc}$ & $0.61 \mathrm{ab}$ & 0.0001 \\
\hline & 27 May & $0.83 \mathrm{a}$ & $0.68 \mathrm{ab}$ & $0.45 \mathrm{c}$ & $0.64 a b c$ & $0.62 \mathrm{bc}$ & 0.0121 \\
\hline & 27 May & $0.94 \mathrm{a}$ & $0.65 \mathrm{~b}$ & $0.36 \mathrm{c}$ & $0.48 \mathrm{~b}$ & $0.66 \mathrm{~b}$ & $<0.001$ \\
\hline
\end{tabular}

${ }^{\mathrm{x}}$ Soil respiration measurements were taken using an EGM-4 gas analyzer with an SRC-1 chamber from PP Systems (Amesbury, MA). Means in a column followed by the same letter are not significantly different at $\alpha=0.05$ according to Fisher's protected least significant difference test; - indicates data not taken. Statistical analysis was conducted using the SAS MIXED procedure.

y UM-LESREC = University of Maryland Lower Eastern Shore Research and Education Center, located in Salisbury, MD; USDA-BARC $=$ United States Department of Agriculture Beltsville Agricultural Research Center, located in Beltsville, MD; UD-REC = University of Delaware's Carvel Research and Education Center, located in Georgetown, DE. Seeding rate at UM-LESREC and UD-REC was V. villosa at $50.44 \mathrm{~kg} / \mathrm{ha}$, T. incarnatum at $11.21 \mathrm{~kg} / \mathrm{ha}, S$. cereale at 125.54 to $134.50 \mathrm{~kg} / \mathrm{ha}$, and $B$. juncea at $11.21 \mathrm{~kg} / \mathrm{ha}$. At USDA-BARC, seeding rate was $V$. villosa at $44.83 \mathrm{~kg} / \mathrm{ha}$, $T$. incarnatum at $28.02 \mathrm{~kg} / \mathrm{ha}, S$. cereale at 134.50 $\mathrm{kg} / \mathrm{ha}$, and $B$. juncea at $6.73 \mathrm{~kg} / \mathrm{ha}$.

${ }^{\mathrm{z}}$ All dates followed by an asterisk $\left(^{*}\right)$ indicate readings taken before cover crop tillage and those without an asterisk were taken following cover crop tillage. 
(UM-LESREC in 2010 and UD-REC in 2011; Table 3). For the other two field trials (UM-LESREC in 2011 and USDA-BARC in 2010), higher $F$. oxysporum also occurred in $V$. villosa-amended plots (36 and 26\% higher) but the differences were not significant. At USDA-BARC in 2010, where there were no significant differences, $V$. villosa-amended plots had numerically more $F$. oxysporum spp. CFU per gram of soil ( 38.0 to 253.7 more CFU per gram of soil) than the other plot treatments. No Fusarium wilt was observed for this field season.

Arbuscular mycorrhizae. The roots of watermelon plants grown following a $V$. villosa and $T$. incarnatum cover crop had significantly higher (55 to $35 \%$ ) arbuscular mycorrhizal colonization than watermelon roots following $S$. cereale or $B$. juncea cover crops or in nonamended plots at UM-LECREC in $2010(P<0.0001$; Table 4). Arbuscular mycorrhizal root colonization was also significantly higher following $S$. cereale (up to $68 \%$ higher) than in watermelon following B. juncea-amended or nonamended plots (Table 4).

At USDA-BARC in 2010, the percentage of mycorrhizal arbuscules was up to $500 \%$ higher in watermelon roots following $V$. villosa cover-crop-amended soil compared with all other amended and nonamended plots $(P<0.0001$; Table 4$)$. Arbuscular mycorrhizal root colonization in $T$. incarnatum-amended plots was intermediate and up to $316 \%$ higher than in S. cereale- or B. juncea-amended and nonamended plots (Table 4).

The Actinovate AG treatment had no significant effect on the percentage of watermelon roots colonized by arbuscular mycorrhizae at either location (data not shown).

Greenhouse experiments. Actinovate AG treatments had no significant main or simple effects on the rate of watermelon linear vine growth during the first experiment. However, during the second experiment, Actinovate AG significantly slowed the rate of vine growth compared with the non-Actinovate AG-treated plants (data not shown).

In both greenhouse experiments, $F$. oxysporum $\mathrm{f}$. sp. niveum inoculations significantly reduced the rate of vine growth in pots amended with legume cover crops while bare soil pots inoculated with $F$. oxysporum f. sp. niveum were not similarly affected (Table 5). However, legume cover crop amendment increased watermelon vine growth (as much as $73 \%$ ) when soil was not inoculated with $F$. oxysporum f. sp. niveum compared with plants in nonamended pots or those amended with S. cereale (Table 5).

To evaluate Fusarium wilt in the greenhouse, field soil was used. Even though this soil was not infested with $F$. oxysporum $\mathrm{f}$. sp. niveum, Fusarium wilt was observed on up to $66 \%$ of the plants in experiment 1 and up to $27 \%$ wilt in experiment 2 . By the end of the experiments, in noninoculated, V. villosa-amended pots, Fusarium wilt severity was reduced up to $98 \%$ compared with watermelon in the $S$. cereale-amended pots for experiment 1 and up to $94 \%$ compared with watermelon in the nonamended pots for experiment 2 (Table 6)

As the greenhouse experiments progressed, Fusarium wilt increased in treatments inoculated with $F$. oxysporum f. sp. niveum and amended with legume cover crops, resulting in disease ratings that were significantly higher compared with their noninoculated counterparts (Table 6). This was not the case for plants in nonamended soil or those amended with $S$. cereale (experiment 1 ), where Fusarium wilt severity was high in both inoculated and noninoculated treatments (Table 6).

Plants inoculated with $F$. oxysporum $\mathrm{f}$. sp. niveum and amended with a legume cover crop developed significantly more wilt than inoculated, nonamended treatments for both experiments. Based on disease severity measured 6 weeks after transplanting in the first greenhouse trial and the AUDPC values in the second greenhouse experiment, plants inoculated with $F$. oxysporum f. sp. niveum and in treatments amended with $V$. villosa had significantly less wilt (as much as a 23 to $26 \%$ lower wilt severity in experiment 1 and experiment 2 , respectively) than plants in $F$. oxysporum f. sp. niveuminoculated treatments amended with $S$. cereale.

In the first greenhouse experiment, 2 weeks after transplanting, Actinovate AG decreased Fusarium wilt severity across all cover crop treatments. Actinovate AG also decreased disease severity in the first experiment in $V$. villosa-amended treatment 4 weeks after transplanting. However, at the same time, T. incarnatum in combination with Actinovate AG increased wilt severity compared with several other treatments. In the second experiment, a three-way interaction occurred between Actinovate AG, $F$. oxysporum f. sp. niveum, and cover crop treatments for week three. Fusarium wilt severity was $22 \%$ higher for plants in pots amended with $S$. cereale + $F$. oxysporum f. sp. niveum + Actinovate AG compared with $S$. cereale $+F$. oxysporum f. sp. niveum but no Actinovate AG. Similarly, Fusarium wilt severity was $46 \%$ higher where watermelon were grown in soil amended with $T$. incarnatum $+F$. oxysporum $\mathrm{f}$. $\mathrm{sp}$. niveum + Actinovate AG compared with $T$. incarnatum $+F$

Table 4. Percentage of watermelon roots colonized by arbuscular mycorrhizae in plots amended with four cover crops and bare ground at the United States Department of Agriculture Beltsville Agricultural Research Center (USDA-BARC) and the University of Maryland Lower Eastern Shore Research and Education Center (UM-LESREC) in 2010

\begin{tabular}{lcc}
\hline & \multicolumn{2}{c}{ Roots colonized $(\%)^{\mathbf{y}}$} \\
\cline { 2 - 3 } Cover crop $^{\mathbf{z}}$ & UM-LESREC & USDA-BARC \\
\hline Vicia villosa & $63.83 \mathrm{a}$ & $84.12 \mathrm{a}$ \\
Trifolium incarnatum & $58.67 \mathrm{a}$ & $56.06 \mathrm{~b}$ \\
Secale cereale & $24.04 \mathrm{~b}$ & $13.48 \mathrm{c}$ \\
Brassica juncea & $14.73 \mathrm{c}$ & $18.84 \mathrm{c}$ \\
Bare ground & $14.30 \mathrm{c}$ & $25.65 \mathrm{c}$ \\
$P>F$ & $<0.0001$ & $<0.0001$ \\
\hline
\end{tabular}

${ }^{\mathrm{y}}$ Means in a column followed by the same letter are not significantly different at $\alpha=0.05$ according to Fisher's protected least significant difference test. Statistical analysis was conducted using the Statistical Analysis System MIXED procedure.

${ }^{\mathrm{z}}$ Seeding rate at UM-LESREC was $V$. villosa $50.44 \mathrm{~kg} / \mathrm{ha}, T$. incarnatum $11.21 \mathrm{~kg} / \mathrm{ha}$, S. cereale $125.54 \mathrm{~kg} / \mathrm{ha}$, B. juncea $11.21 \mathrm{~kg} / \mathrm{ha}$ and at USDA-BARC the seeding rate was $V$. villosa $44.83 \mathrm{~kg} / \mathrm{ha}$, $T$. incarnatum $28.02 \mathrm{~kg} / \mathrm{ha}$, S. cereale $134.50 \mathrm{~kg} / \mathrm{ha}$, and B. juncea $6.73 \mathrm{~kg} / \mathrm{ha}$.

Table 3. Effects of cover crop treatments on Fusarium oxysporum in soil for four field experiments ${ }^{\mathrm{x}}$

\begin{tabular}{lcccc}
\hline & \multicolumn{4}{c}{ Location, year (CFU/g) $^{\mathbf{y}}$} \\
\cline { 2 - 5 } Cover crop $^{\mathbf{z}}$ & USDA-BARC 2010 & UM-LESREC 2010 & UM-LESREC 2011 & UD-REC 2011 \\
\hline Vicia villosa & 713.62 & $228.74 \mathrm{a}$ & 330.12 & $842.57 \mathrm{a}$ \\
Trifolium incarnatum & 525.02 & - & 305.37 & $727.48 \mathrm{ab}$ \\
Brassica juncea & 459.91 & $102.73 \mathrm{~b}$ & 279.59 & $664.26 \mathrm{ab}$ \\
Secale cereale & 675.05 & $139.74 \mathrm{~b}$ & 258.92 & $17.30 \mathrm{c}$ \\
Bare ground & 568.29 & $149.29 \mathrm{~b}$ & 242.54 & $165.75 \mathrm{bc}$ \\
$P>F$ & 0.3615 & 0.0086 & 0.3855 & 0.0262 \\
\hline
\end{tabular}

${ }^{\mathrm{x}}$ UM-LESREC = University of Maryland Lower Eastern Shore Research and Education Center, located in Salisbury, MD; USDA-BARC = United States Department of Agriculture Beltsville Agricultural Research Center, located in Beltsville, MD; UD-REC = University of Delaware's Carvel Research and Education Center, located in Georgetown, DE.

${ }^{y}$ Means in a column followed by the same letter are not significantly different at $\alpha=0.05$ according to Fisher's protected least significant difference test; - indicates data not taken. Statistical analysis was conducted using the Statistical Analysis System MIXED procedure.

${ }^{\mathrm{z}}$ Seeding rate at UM-LESREC and UD-REC was $V$. villosa at $50.44 \mathrm{~kg} / \mathrm{ha}, T$. incarnatum at $11.21 \mathrm{~kg} / \mathrm{ha}$, S. cereale at 125.54 to $134.50 \mathrm{~kg} / \mathrm{ha}$, and B. juncea at $11.21 \mathrm{~kg} / \mathrm{ha}$. At USDA-BARC, the seeding rate was $V$. villosa at $44.83 \mathrm{~kg} / \mathrm{ha}, T$. incarnatum at $28.02 \mathrm{~kg} / \mathrm{ha}$, S. cereale at $134.50 \mathrm{~kg} / \mathrm{ha}$, and $B$. juncea at $6.73 \mathrm{~kg} / \mathrm{ha}$. 
oxysporum f. sp. niveum without Actinovate AG. The only significant pattern observed across both experiments was that the application of Actinovate AG can increase wilt severity, particularly when in combination with a $T$. incarnatum green manure (data not shown). Streptomyces lydicus was not isolated from watermelon rhizosphere in either trial.

In vitro assays. Leachate assays. In the first plate assay, logarithmic radial growth of $F$. oxysporum $\mathrm{f}$. sp. niveum at $\mathrm{pH} 3.5$ was fastest on all media amended with a legume cover crop leachate, intermediate on Secale cereale-amended media, and slowest on nonamended media (Table 7). In the second assay, F. oxysporum f. sp. niveum logarithmic growth at $\mathrm{pH} 3.5$ was faster on $V$. villosa $1 \times$ amended media compared with nonamended and $S$. cereale-amended media (Table 7).

Table 5. Effects of cover crop and Fusarium oxysporum f. sp. niveum (FON) inoculation on the linear rate of Sugar Heart watermelon vine growth in two greenhouse experiments (Exp)

\begin{tabular}{|c|c|c|c|}
\hline \multirow[b]{2}{*}{ Amendments ${ }^{y}$} & \multirow[b]{2}{*}{ Inoculum $^{\mathrm{z}}$} & \multicolumn{2}{|c|}{ Vine length $(\mathrm{mm} / \text { week })^{x}$} \\
\hline & & $\operatorname{Exp} 1$ & $\operatorname{Exp} 2$ \\
\hline Vicia villosa $1 \times$ & FON & $0.96 \mathrm{cdef}$ & $7.84 \mathrm{~d}$ \\
\hline V. villosa $2 \times$ & FON & 0.84 def & $6.80 \mathrm{~d}$ \\
\hline V. villosa $3 \times$ & FON & $0.67 \mathrm{ef}$ & $7.14 \mathrm{~d}$ \\
\hline Trifolium incarnatum & FON & $0.49 \mathrm{f}$ & $1.15 \mathrm{e}$ \\
\hline Secale cereale & FON & 0.52 ef & $6.97 \mathrm{~d}$ \\
\hline Nonamended & FON & 1.14 cde & $17.84 \mathrm{ab}$ \\
\hline V. villosa $1 \times$ & No FON & $1.83 \mathrm{ab}$ & $17.27 \mathrm{ab}$ \\
\hline V. villosa $2 \mathrm{x}$ & No FON & $1.48 \mathrm{bcd}$ & $20.26 \mathrm{a}$ \\
\hline$V$. villosa $3 \times$ & No FON & $1.92 \mathrm{ab}$ & $17.88 \mathrm{ab}$ \\
\hline T. incarnatum & No FON & $2.25 \mathrm{a}$ & $17.95 \mathrm{ab}$ \\
\hline S. cereale & No FON & 0.74 ef & $11.71 \mathrm{c}$ \\
\hline Nonamended & No FON & $1.53 \mathrm{bc}$ & $16.26 \mathrm{~b}$ \\
\hline$P>F$ & $\ldots$ & 0.0096 & $<0.0001$ \\
\hline
\end{tabular}

${ }^{\mathrm{x}}$ Watermelon vine length was measured weekly every week for 6 weeks and the rate of linear vine growth in millimeters per week was calculated. Means in a column followed by the same letter are not significantly different at $\alpha=$ 0.05 according to Fisher's protected least significant difference test. Statistical analysis was conducted using the Statistical Analysis System MIXED procedure.

${ }^{y} \mathrm{~V}$. villosa green manure amendment was incorporated into the soil at three different rates: $2,721.55 \mathrm{~kg} / \mathrm{ha}(1 \times), 3,685.43 \mathrm{~kg} / \mathrm{ha}(2 \times)$, and $5,669.88$ $\mathrm{kg} / \mathrm{ha}(3 \times) . T$. incarnatum was incorporated into the soil at $5,102.90 \mathrm{~kg} / \mathrm{ha}$ and $S$. cereale was incorporated at $3,968.90 \mathrm{~kg} / \mathrm{ha}$.

${ }^{\mathrm{z}} \mathrm{FON}$ inoculum was incorporated into soil at $25,000 \mathrm{CFU} / \mathrm{g}$ of soil.
There were no significant treatment differences in $F$. oxysporum f. sp. niveum logarithmic growth at $\mathrm{pH} 6$ in the first assay. However, for the second assay, $F$. oxysporum $\mathrm{f}$. sp. niveum logarithmic growth was fastest on $V$. villosa $1 \times$ amended media compared with all other treatments (as much as 15.4\%), except for that of $V$. villosa $2 \times$ amended media (Table 7).

Logarithmic growth rates of Trichoderma harzianum at $\mathrm{pH} 3.5$ were significantly faster on $V$. villosa $1 \times$ and $2 \times$ media in the first assay and on $V$. villosa $1 \times$ in the second assay compared with all other treatments (as much as $16.7 \mathrm{~mm}$ per $24 \mathrm{~h}$; Table 7).

The logarithmic rate of growth of T. harzianum at $\mathrm{pH} 6$ in the first assay was significantly faster on $V$. villos $1 \times$ and $2 \times$ amended media than on Trifolium incarnatum or nonamended media. The logarithmic growth rates of Trichoderma harzianum in the second assay done at $\mathrm{pH} 6$ were faster on $V$. villosa $1 \times$ compared with all other leachateamended and nonamended media, except for that of $V$. villosa $2 \times$ (as much as $6.6 \%$; Table 7).

All F. oxysporum f. sp. niveum and T. harzianum fungi were found to be viable after growth had reached the edge of the plate or had slowed. No abnormal mycelial growth was observed.

Streptomyces lydicus assays. F. oxysporum f. sp. niveum linear growth rate was significantly inhibited (up to 1.8 times) on plates coinoculated with Streptomyces lydicus compared with the linear growth rate on control plates for both experiments (Table 8). In the first assay, $F$. oxysporum $\mathrm{f}$. sp. niveum linear growth was significantly slower on plates streaked with the S. lydicus WYEC 108 pure isolate compared with plates streaked with $S$. lydicus isolated from the commercial Actinovate AG product; however, the opposite relationship occurred in the second assay (Table 8). Abnormal mycelial growth, in the form of a terminal mass of hyphae, was observed at the line of inhibition. However, F. oxysporum f. sp. niveum growth was normal when the mycelia were transferred to nonamended PDA plates.

\section{Discussion}

The general increases in respiration measurements following legume cover crop amendments, indicative of increased microbial activity, were significantly negatively correlated with Fusarium wilt severity. Similarly, a previous study established a positive relationship between $V$. villosa cover crop incorporation, the suppression of Fusarium wilt of watermelon, and elevated soil bacterial populations (Zhou and Everts 2007). These increases in overall soil microbial activity following a legume cover crop are indicative of general disease suppression. Although the respiration measurement results signify that general suppression plays

Table 6. Effects of cover crop and Fusarium oxysporum f. sp. niveum (FON) inoculation on Sugar Heart watermelon wilt severity in two greenhouse experiments ${ }^{\mathrm{x}}$

\begin{tabular}{|c|c|c|c|c|c|c|c|}
\hline \multirow[b]{2}{*}{ Cover crop $^{y}$} & \multirow[b]{2}{*}{ Inoculum $^{z}$} & \multicolumn{3}{|c|}{ Trial 1} & \multicolumn{3}{|c|}{ Trial 2} \\
\hline & & Week 4 & Week 6 & AUDPC & Week 4 & Week 6 & AUDPC \\
\hline Vicia villosa $1 \times$ & FON & $20.50 \mathrm{ab}$ & $38.21 \mathrm{bc}$ & $97.19 \mathrm{abc}$ & $4.04 \mathrm{c}$ & $50.54 \mathrm{~b}$ & $62.90 \mathrm{~cd}$ \\
\hline V. villosa $2 \times$ & FON & $13.67 \mathrm{abc}$ & $45.08 \mathrm{ab}$ & $78.76 \mathrm{bcd}$ & $4.04 \mathrm{c}$ & $54.75 \mathrm{~b}$ & $73.71 \mathrm{bc}$ \\
\hline V. villosa $3 \times$ & FON & $4.04 \mathrm{bc}$ & $44.12 \mathrm{ab}$ & $60.43 \mathrm{cde}$ & $6.83 \mathrm{bc}$ & $73.63 \mathrm{a}$ & $101.73 \mathrm{~b}$ \\
\hline Trifolium incarnatum & FON & $25.33 \mathrm{a}$ & $64.92 \mathrm{a}$ & $150.10 \mathrm{a}$ & $53.29 \mathrm{a}$ & $73.79 \mathrm{a}$ & $192.69 \mathrm{a}$ \\
\hline Secale cereale & FON & $14.42 \mathrm{abc}$ & $64.33 \mathrm{a}$ & $128.19 \mathrm{ab}$ & $18.46 \mathrm{~b}$ & $51.92 \mathrm{~b}$ & $103.21 \mathrm{~b}$ \\
\hline Nonamended & FON & $5.00 \mathrm{bc}$ & $15.54 \mathrm{~d}$ & 40.73 cdef & $4.79 \mathrm{bc}$ & $20.71 \mathrm{c}$ & $18.06 \mathrm{e}$ \\
\hline V. villosa $1 \times$ & No FON & $6.83 \mathrm{bc}$ & $6.83 \mathrm{~d}$ & $18.83 \mathrm{ef}$ & $0.00 \mathrm{c}$ & $6.88 \mathrm{~d}$ & $3.44 \mathrm{e}$ \\
\hline V. villosa $2 \times$ & No FON & $0.00 \mathrm{c}$ & $17.08 \mathrm{~cd}$ & $11.20 \mathrm{ef}$ & $0.00 \mathrm{c}$ & $1.42 \mathrm{~d}$ & $0.71 \mathrm{e}$ \\
\hline V. villosa $3 \times$ & No FON & $0.00 \mathrm{c}$ & $0.75 \mathrm{~d}$ & $0.38 \mathrm{f}$ & $0.75 \mathrm{c}$ & $13.75 \mathrm{~cd}$ & $9.88 \mathrm{e}$ \\
\hline T. incarnatum & No FON & $0.00 \mathrm{c}$ & $5.00 \mathrm{~d}$ & $2.50 \mathrm{ef}$ & $0.75 \mathrm{c}$ & $27.46 \mathrm{c}$ & $12.56 \mathrm{e}$ \\
\hline S. cereale & No FON & $0.00 \mathrm{c}$ & $66.29 \mathrm{a}$ & 58.44 cde & $2.17 \mathrm{c}$ & $19.29 \mathrm{~cd}$ & $27.85 \mathrm{de}$ \\
\hline Nonamended & No FON & $0.00 \mathrm{c}$ & $20.83 \mathrm{~cd}$ & 18.77 ef & $0.00 \mathrm{c}$ & $25.38 \mathrm{c}$ & $18.52 \mathrm{e}$ \\
\hline$P>F$ & $\ldots$ & 0.0190 & 0.0001 & 0.0001 & $<0.0001$ & $<0.0001$ & $<0.0001$ \\
\hline
\end{tabular}

${ }^{x}$ Means in a column followed by the same letter are not significantly different at $\alpha=0.05$ according to Fisher's protected least significant difference test. Statistical analysis was conducted using the SPPS Statistics 23, and data were back transformed to the midpoint of the associated severity range prior to analysis. Area under the disease progress curve (AUDPC) was calculated from six weekly Fusarium wilt severity ratings using trapezoidal integration. Watermelon wilt severity was rated on a scale of 0 to 3 , where $0=$ no wilt, $1=1$ to $33 \%$ wilted, $2=34$ to $63 \%$ wilted, and $3=64$ to $100 \%$ wilted or dead.

${ }^{y} V$. villosa green manure amendment was incorporated into the soil at three different rates: $2,721.55 \mathrm{~kg} / \mathrm{ha}(1 \times), 3,685.43 \mathrm{~kg} / \mathrm{ha}(2 \times)$, and $5,669.88 \mathrm{~kg} / \mathrm{ha}(3 \times)$. T. incarnatum was incorporated into the soil at $5,102.90 \mathrm{~kg} / \mathrm{ha}$ and $S$. cereale was incorporated at $3,968.90 \mathrm{~kg} / \mathrm{ha}$.

${ }^{z} \mathrm{FON}$ inoculum was incorporated into soil at $25,000 \mathrm{CFU} / \mathrm{g}$ of soil. 
a role in legume green-manure-mediated reductions in Fusarium wilt of watermelon, results of soil dilution assays, mycorrhizae assessments, greenhouse experiments, and in vitro assays also support the hypothesis that specific suppression is contributing to Fusarium wilt reductions.

Fusarium wilt suppression occurred following a legume green manure in our field trials. However, in greenhouse experiments, Fusarium wilt severity increased when plants were inoculated with $F$. oxysporum f. sp. niveum and grown in soil amended with either $V$. villosa or Trifolium incarnatum as compared with no amendment. In addition, watermelon inoculated with $F$. oxysporum f. sp. niveum and amended with larger amounts of biomass (namely, V. villosa $2 \times$ and $3 \times$ ) had significantly higher wilt severity ratings than watermelon in all other inoculated, covercrop-amended treatments. The extra biomass, which had not completely decomposed after the 2-week incubation, may have stimulated chlamydospore germination. Immature cover crop residues, characterized as having a low $\mathrm{C}: \mathrm{N}$ ratio, have been demonstrated to increase chlamydospore germination of $F$. solani (Lewis and Papavizas 1977) and are associated with low levels of disease suppression of Pythium spp. and Rhizoctonia solani (Grünwald et al. 2000). However, as cover crop residues decompose, the stimulatory effect on germination decreases. The optimum duration of cover crop decomposition to minimize the stimulatory effect depends on soil temperature, soil moisture, and other factors such as tillage frequency (Miller and Burke 1980). However, the time is usually more than 2 weeks.

In our greenhouse experiments where cover crops were incorporated and compared with nonamended controls, there was likely a stimulation of chlamydospore germination which led to increased Fusarium wilt severity. However, plants in $F$. oxysporum f. sp. niveum-inoculated, $V$. villosa $1 \times$ amended treatments developed significantly less wilt than those inoculated and grown in soil amended with Secale cereale or T. incarnatum. This may indicate that the cover-crop-mediated suppression can be negated by both high pathogen inoculum levels and transplanting watermelon too soon after cover crop amendment.

In addition to stimulation of chlamydospore germination, other explanations could exist for the increased Fusarium wilt severity of plants in soil inoculated with $F$. oxysporum $\mathrm{f}$. sp. niveum and amended with legume cover crops. Only dried aboveground biomass of $V$. villosa was used for the greenhouse experiments. It is possible that the roots of $V$. villosa are necessary for attaining the level of microbial activity that contributes to the disease-suppressive effects seen in the field. For example, in some studies, $V$. villosa roots increase soil microbial biomass significantly more than the shoots (Buyer et al. 2010). The effect of $V$. villosa roots versus aboveground biomass may be explained by the fact that $V$. villosa is generally planted in the fall preceding watermelon planting and grows throughout the fall and during the early spring, resulting in many months of rhizosphere influence on the soil ecosystem, including soil, water, and nutrient dynamics; secondary product exudation; and organic matter deposition.

In soils where Fusarium wilt suppression is natural or induced, a complement of general and more specific mechanisms of suppression (namely, nonpathogenic F. oxysporum spp. and fluorescent Pseudomonas spp.) are cited as the means for reductions in Fusarium wilt of watermelon (Larkin et al. 1993a,b, 1996). The legume Pueraria javanica, used as a cover plant, reduced Fusarium wilt of a palm-grove crop (Abadie et al. 1998), where the wilt reductions were attributed to increased populations of and competition from nonpathogenic $F$. oxysporum spp. In the absence of a host, nonpathogenic $F$. oxysporum spp. and $F$. oxysporum $\mathrm{f}$. sp. niveum occupy a similar saprophytic niche, possessing comparable nutrient requirements (Lamanceau et al. 1993). Competition among $F$. oxysporum spp. for nutrients such as glucose often results in the reduction of $F$. oxysporum $f$. sp. niveum growth and virulence (Alabouvette et al. 1993; Lamanceau et al. 1993; Zhou and Everts 2003). Additionally, intraspecies interaction is largely dependent on the ratio of nonpathogenic to pathogenic $F$. oxysporum populations; the higher the ratio, the greater the antagonism (Lamanceau

Table 8. Effects of two isolates of Streptomyces lydicus (Actinovate AG and WYEC 108) on total growth by day 12 and in vitro linear growth rate of Fusarium oxysporum $\mathrm{f}$. sp. niveum for two assays $\mathrm{s}^{\mathrm{x}}$

\begin{tabular}{lcc}
\hline & \multicolumn{2}{c}{ Growth $^{\mathbf{y}}$} \\
\cline { 2 - 3 } Treatment $^{\mathbf{z}}$ & Total $(\mathbf{m m})$ & Linear rate $(\mathbf{m m} / \mathbf{h})$ \\
\hline Assay 1 & $57.00 \mathrm{a}$ & $4.60 \mathrm{a}$ \\
Control & $37.34 \mathrm{~b}$ & $3.10 \mathrm{~b}$ \\
Actinovate AG & $36.88 \mathrm{~b}$ & $2.86 \mathrm{c}$ \\
WYEC 108 & $<0.0001$ & $<0.0001$ \\
$P>F$ & & \\
Assay 2 & $60.00 \mathrm{a}$ & $4.89 \mathrm{a}$ \\
Control & $39.06 \mathrm{~b}$ & $2.73 \mathrm{c}$ \\
Actinovate AG & $37.67 \mathrm{c}$ & $2.93 \mathrm{~b}$ \\
WYEC 108 & $<0.0001$ & $<0.0001$ \\
$P>F$ &
\end{tabular}

${ }^{\mathrm{x}}$ S. lydicus WYEC 108 is the active ingredient in Actinovate $\mathrm{AG}$, a biocontrol product made by Natural Industries.

y Means in a column followed by the same letter are not significantly different at $\alpha=0.05$ according to Fisher's protected least significant difference test. Statistical analysis was conducted using the Statistical Analysis System MIXED procedure.

${ }^{\mathrm{z}}$ Control plates were potato dextrose agar plates inoculated with $F$. oxysporum f. sp. niveum but not $S$. lydicus.

Table 7. Logarithmic rate of radial growth of Fusarium oxysporum f. sp. niveum and Trichoderma harzianum on potato dextrose agar plates amended with cover crop leachate

\begin{tabular}{|c|c|c|c|c|c|c|c|c|}
\hline \multirow[b]{4}{*}{ Leachate $^{\mathrm{z}}$} & \multicolumn{8}{|c|}{ Radial growth $(\mathrm{mm} / \mathrm{h})^{y}$} \\
\hline & \multicolumn{4}{|c|}{ F. oxysporum f. sp. niveum } & \multicolumn{4}{|c|}{ T. harzianum } \\
\hline & \multicolumn{2}{|c|}{ pH 3.5} & \multicolumn{2}{|c|}{ pH 6.0 } & \multicolumn{2}{|c|}{ pH 3.5} & \multicolumn{2}{|c|}{ pH 6.0} \\
\hline & Assay 1 & $\overline{\text { Assay } 2}$ & Assay 1 & $\overline{\text { Assay } 2}$ & Assay 1 & $\overline{\text { Assay } 2}$ & Assay 1 & $\overline{\text { Assay } 2}$ \\
\hline$\overline{\text { Vicia villosa } 1 \times}$ & $26.34 \mathrm{a}$ & $26.19 \mathrm{a}$ & $25.07 \mathrm{a}$ & $27.72 \mathrm{a}$ & $44.88 \mathrm{a}$ & $31.43 \mathrm{a}$ & $66.05 \mathrm{a}$ & $32.96 \mathrm{a}$ \\
\hline V. villosa $2 \times$ & $27.29 \mathrm{a}$ & $24.89 \mathrm{ab}$ & $24.77 \mathrm{a}$ & $26.43 \mathrm{ab}$ & $45.18 \mathrm{a}$ & $26.71 \mathrm{~b}$ & $66.91 \mathrm{a}$ & $32.07 \mathrm{ab}$ \\
\hline Trifolium incarnatum & $26.45 \mathrm{a}$ & $24.49 \mathrm{ab}$ & $27.22 \mathrm{a}$ & $25.25 \mathrm{~b}$ & $28.19 \mathrm{~b}$ & $26.57 \mathrm{~b}$ & $63.45 \mathrm{bc}$ & $31.58 \mathrm{~b}$ \\
\hline Secale cereale & $24.46 \mathrm{~b}$ & $23.38 \mathrm{~b}$ & $25.00 \mathrm{a}$ & $24.03 \mathrm{~b}$ & $28.18 \mathrm{~b}$ & $26.61 \mathrm{~b}$ & $65.05 \mathrm{ab}$ & $31.48 \mathrm{~b}$ \\
\hline Nonamended & $22.83 \mathrm{c}$ & $23.51 \mathrm{~b}$ & $24.53 \mathrm{a}$ & $24.57 \mathrm{~b}$ & $29.49 \mathrm{~b}$ & $27.68 \mathrm{~b}$ & $61.44 \mathrm{c}$ & $31.43 \mathrm{~b}$ \\
\hline$P>F$ & $<0.0001$ & 0.0230 & 0.6256 & 0.0206 & $<0.0001$ & $<0.0001$ & 0.0174 & 0.0070 \\
\hline
\end{tabular}

${ }^{\mathrm{y}}$ For assay 1, radial growth measurements were taken every $24 \mathrm{~h}$ for 24 days at $\mathrm{pH} 3.5$ and every $24 \mathrm{~h}$ for 16 days for $\mathrm{pH}$. For assay 2 , measurements were taken 10 times every $6 \mathrm{~h}$, again after $12 \mathrm{~h}$, and then every $24 \mathrm{~h}$ for 19 days. Means in a column followed by the same letter are not significantly different at $\alpha=0.05$ according to Fisher's protected least significant difference test. Statistical analysis was conducted using the Statistical Analysis System MIXED procedure.

${ }^{\mathrm{z}}$ Amounts of cover crop biomass used was representative of field conditions (T. incarnatum at 5,101.88 kg/ha, S. cereal at $3,968.13 \mathrm{~kg} / \mathrm{ha}, V$. villosa $1 \times$ at $2,834.38 \mathrm{~kg} / \mathrm{ha}$, and $V$. villosa $2 \times$ at $5,668.75 \mathrm{~kg} / \mathrm{ha}$ ). Leachate was collected at twice the concentration of these field conditions for $S$. cereale and $T$. incarnatum and four times the concentration for V. villosa so that, after potato dextrose agar (PDA) was made, it was brought up to volume with the leachate to achieve field leachate concentrations. Control plates were nonamended PDA. 
et al. 1993). Nonpathogenic $F$. oxysporum and $F$. oxysporum f. sp. niveum cannot be distinguished using morphological traits, making study of the role of nonpathogenic $F$. oxysporum in disease suppression difficult. In addition, genetic similarities among $F$. oxysporum spp. have resulted in only the recent identification of primer sequences for select formae specialis, with varying sensitivity, making molecular enumeration of changes in $F$. oxysporum spp. populations versus $F$. oxysporum $\mathrm{f}$. sp. niveum populations difficult to measure for this study (Everts and Himmelstein 2015; Lin et al. 2010). No molecular methodology is currently available for differentiating $F$. oxysporum f. sp. niveum races (Everts and Himmelstein 2015).

Cover crop incorporation also affects other common soilborne fungi that may have a role in Fusarium wilt suppression. For example, Trichoderma harzianum growth was stimulated on $V$. villosa leachate-amended plates. Trichoderma spp. are often used as indicator species to track elevated levels of microbes antagonistic to soil pathogens (Bailey et al. 2008; Bonanomi et al. 2010; Buśko et al. 2008). However they also induce systemic acquired resistance, and are frequently utilized as a biocontrol for plant pathogens (Rojo et al. 2007; Wu et al. 2009; Yang et al. 2011). In addition, F. oxysporum f. sp. niveum growth was stimulated by the presence of $V$. villosa cover crop leachates. This contrasts with Brassica spp. cover crops, where leachates were fungitoxic and led to reductions in plant pathogens such as Gaeumannomyces graminis (Angus et al. 1994; Kirkegaard and Sarwar 1998).

The active ingredient of Actinovate AG, Streptomyces lydicus WYEC108, was developed as a commercial biocontrol product due to its successful in vitro growth and antagonism to plant pathogens (Tokala et al. 2002; Yuan and Crawford 1995). Here, we demonstrated S. lydicus's limited efficacy at inhibiting the in vitro growth of the $F$. oxysporum f. sp. niveum pathogen. The inconsistent and minimal effects of Actinovate AG on Fusarium wilt of watermelon in the greenhouse experiments were consistent with findings from previous field trials (Himmelstein et al. 2014). It is likely that the field conditions in Maryland in which F. oxysporum f. sp. niveum flourishes are not conducive to the growth and efficacy of $S$. lydicus (Himmelstein et al. 2014; Kinkel et al. 2012).

Minimal information is available on arbuscular mycorrhizae and their effects on watermelon cropping systems, particularly on disease management. Only in a recent study was it demonstrated that arbuscular mycorrhizal colonization of watermelon roots effectively reduced Fusarium wilt severity and influenced watermelon root exudate composition (Ren et al. 2015). V. villosa and Trifolium incarnatum green manure amendments increased the percentage of watermelon roots colonized by arbuscular mycorrhiza compared with watermelon roots in all other amended and nonamended plots for both field locations. This is consistent with research that has demonstrated that $V$. villosa increases arbuscular mycorrhizal soil inoculum levels and root colonization of subsequent crops of several plant species (Galvez et al. 1995; Njeru et al. 2014). It is possible that increased levels of arbuscular mycorrhizal colonization of watermelon roots due to a preceding legume cover crop is a specific mode of suppression that is, in part, contributing to reductions in Fusarium wilt of watermelon.

Plants from the Brassicaceae family can decrease soil mycorrhizae populations, resulting in reduced mycorrhizal root colonization of future field crops and the presence, as opposed to absence, of compatible host plant roots can help sustain and increase soil arbuscular mycorrhizal populations (Kabir and Koide 2000; Roberts and Anderson 2001; Schreiner and Koide 1993). Additionally, Brassica spp. green manure amendments have been associated with numerical increases in the severity of Fusarium wilt of watermelon and increased F. oxysporum spp. sporulation (Himmelstein et al. 2014; Smolinska et al. 2003). Two of the primary means by which arbuscular mycorrhizae protect their plant host from pathogen infection are induced systemic resistance and impact on microbial communities in the plant rhizosphere through changes in plant host root exudates (Kapoor 2008; Martínez-Medina et al. 2009). Both induced systemic resistance and rhizosphere community changes were associated with Fusarium wilt suppression on watermelon and blueberry (Larkin et al. 1993a; Montalba et al. 2010; Wu et al. 2009). Grower inoculation of watermelon with arbuscular mycorrhizal is not a common practice. Additional research on the efficacy of arbuscular mycorrhizal inoculation is needed prior to more widespread adoption.

Both $V$. villosa and $T$. incarnatum similarly affected soil respiration and mycorrhizal colonization of watermelon roots in these studies. However, the effects of $T$. incarnatum were often lower in magnitude and not always statistically significant in comparison with $V$. villosa. Likewise, the degree to which these two legume green manures reduce disease differed, and $T$. incarnatum was less likely to suppress Fusarium wilt (a difference of 3.5 to $7.5 \%$ ). If more specific processes are involved in addition to the general disease suppression, then strategic management practices that promote the actions of these specific mechanisms such as inoculations of nonpathogenic $F$. oxysporum spp., arbuscular mycorrhizal, or other microbial antagonists could enhance the disease suppressive effects of T. incarnatum or $V$. villosa.

\section{Literature Cited}

Abadie, C., Edel, V., and Alabouvette, C. 1998. Soil suppressiveness to Fusarium wilt: Influence of a cover-plant on density and diversity of Fusarium populations. Soil Biol. Biochem. 30:643-649.

Alabouvette, C., Louvet, J., and Couteaudier, Y. 1985. Disease suppressiveness of soils. XII. Respiratory activity after addition of glucose to a wilt-suppressive and a wilt-conducive soil. Agronomie 5:69-72.

Alabouvette, C., Steinberg, C., and Lemanceau, P. 1993. Recent advances in the biological control of Fusarium wilts. Pestic. Sci. 37:365-373.

Al-Reza, S. M., Rahman, A., Ahmed, Y., and Kang, S. C. 2010. Inhibition of plant pathogens in vitro and in vivo with essential oil and organic extracts of Cestrum nocturnum L. Pestic. Biochem. Physiol. 96:86-92.

Angus, J. F., Gardner, P. A., Kirkegaard, J. A., and Desmarchelier, J. M. 1994 Biofumigation: Isothiocyanates released from Brassica roots inhibit growth of the take-all fungus. Plant Soil 162:107-112.

Bailey, B. A., Bae, H., Strem, M. D., Crozier, J., Thomas, S. E., Samuels, G. J. Vinyard, B. T., and Holmes, K. A. 2008. Antibiosis, mycoparasitism, and colonization success for endophytic Trichoderma isolates with biological control potential in Theobroma cacao. Biol. Control 46:24-35.

Bonanomi, G., Antignani, V., Capodilupo, M., and Scala, F. 2010. Identifying the characteristics of organic soil amendments that suppress soilborne plant diseases. Soil Biol. Biochem. 42:136-144.

Buśko, M., Chellkowsi, J., Popiel, D., and Perkowski, J. 2008. Solid substrate bioassay to evaluate impact of Trichoderma on trichothecene mycotoxin production by Fusarium species. J. Sci. Food Agric. 88:536-541.

Buyer, J. S., Teasdale, J. R., Roberts, D. P., Zasada, I. A., and Maul, J. E. 2010 Factors affecting soil microbial community structure in tomato cropping systems. Soil Biol. Biochem. 42:831-841.

Cordier, C., Pozo, M. J., Barea, J. M., Gianinazzi, S., and Gianinazzi-Pearson, V. 1998. Cell defense responses associated with localized and systemic resistance to Phytophthora parasitica induced in tomato by an arbuscular mycorrhizal fungus. Mol. Plant-Microbe Interact. 11:1017-1028.

Dubey, S. C., Suresh, M., and Singh, B. 2007. Evaluation of Trichoderma species against Fusarium oxysporum f. sp. ciceris for integrated management of chickpea wilt. Biol. Control 40:118-127.

Egerton-Warburton, L. M., and Allen, E. B. 2000. Shifts in arbuscular mycorrhizal communities along an anthropogenic nitrogen deposition gradient. Ecol. Appl. 10:484-496.

Elmer, W. H., and McGovern, R. J. 2004. Efficacy of integrating biologicals with fungicides for the suppression of Fusarium wilt of cyclamen. Crop Prot. 23: 909-914.

Eshel, D., Gamliel, A., Grinstein, A., DiPrimo, P., and Katan, J. 2000. Combined soil treatments and sequence of application in improving the control of soilborne pathogens. Phytopathology 90:751-757.

Everts, K. L., and Himmelstein, J. 2015. Fusarium wilt of watermelon: Towards sustainable management of a re-emerging plant disease. Crop Prot. 73: 93-99.

Everts, K. L., and Hochmuth, M. 2011. Field evaluation of triploid cultivars for resistance to Fusarium wilt of watermelon in Delaware, 2010. Online publication. Plant Dis. Manage. Rep. 5:V175.

Everts, K. L., and Zhou, X. G. 2010. Field evaluation of triploid cultivars for resistance to Fusarium wilt of watermelon in Delaware, 2009. Online publication. Plant Dis. Manage. Rep. 4:V066.

Ferguson, W., and Yee, J. 1997. Phasing out registered pesticide uses as an alternative to total bans: A case study of methyl bromide. J. Agribus. 15:69-84.

Galvez, L., Douds, D. D., Wagoner, P., Longnecker, L. R., Drinkwater, L. E., and Janke, R. R. 1995. An overwintering cover crop increases inoculum of VAM fungi in agricultural soil. Am. J. Altern. Agric. 10:152-156. 
Getha, K., Vikineswary, S., Wong, W. H., Seki, T., Ward, A., and Goodfellow, M. 2005. Evaluation of Streptomyces spp. strain g10 for suppression of Fusarium wilt and rhizosphere colonization in pot-grown banana plantlets. J. Ind. Microbiol. Biotechnol. 32:24-32.

Grünwald, N. J., Hu, S., and van Bruggen, A. H. C. 2000. Short-term cover crop decomposition in organic and conventional soils: Characterization of soil $\mathrm{C}, \mathrm{N}$, microbial and plant pathogen dynamics. Eur. J. Plant Pathol. 106:37-50.

Gullino, M. L., Camponogara, A., Gasparrini, G., Rizzo, V., Clini, C., and Garibaldi, A. 2003. Replacing methyl bromide for soil disinfestation: The Italian experience and implications for other countries. Plant Dis. 87: 1012-1021.

Henn, A., and Burdine, A. 2010. Management of Fusarium surface rot of sweet potatoes after packing in Mississippi, 2009. Online publication. Plant Dis. Manage. Rep. 4:V109.

Himmelstein, J., C., Maul, J. E., Everts, K., E. 2014. Impact of five cover crop green manures and Actinovate on Fusarium wilt of watermelon. Plant Dis. 98:965-972.

Howell, C. R. 2003. Mechanisms employed by Trichoderma species in the biological control of plant diseases: The history and evolution of current concepts. Plant Dis. 87:4-10.

Jones, J. P., Woltz, S. S., and Everett, P. H. 1976. Effect of liming and nitrogen source on Fusarium wilt of cucumber and watermelon. Proc. Fla. State Hortic. Soc. 88:200-203.

Kabir, Z., and Koide, R. T. 2000. The effect of dandelion or a cover crop on mycorrhizal inoculum potential, soil aggregation and yield of maize. Agric. Ecosyst. Environ. 78:167-174.

Kapoor, R. 2008. Induced resistance in mycorrhizal tomato is correlated to concentration of jasmonic acid. Online J. Biol. Sci. 8:49-56.

Kaya, C., Higgs, D., Kirnak, H., and Tas, I. 2003. Mycorrhizal colonization improves fruit yield and water use efficiency in watermelon (Citrullus lanatus Thunb.) grown under well-watered and water-stressed conditions. Plant Soil 253:287-292.

Keinath, A. P., Hassell, R. L., Everts, K. L., and Zhou, X.-G. 2010. Cover crops of hybrid common vetch reduce Fusarium wilt of seedless watermelon in the eastern United States. Online publication. Plant Health Prog. doi:10.1094/ PHP-2010-0914-01-RS

Kinkel, L. L., Schlatter, D. C., Bakker, M. G., and Arenz, B. E. 2012. Streptomyces, competition and co-evolution in relation to plant disease suppression. Res. Microbiol. 163:490-499.

Kirkegaard, J. A., and Sarwar, M. 1998. Biofumigation potential of brassicas I. Variation in glucosinolate profiles of diverse field-grown brassicas. Plant Soil 201:71-89.

Komada, H. 1975. Development of a selective medium for quantitative isolation of Fusarium oxysporum from natural soil. Rev. Plant Prot. Res. 8:115-125.

Korhonen, J. F. J., Pumpanen, J., Kolari, P., Juurola, E., and Nikinmaa, E. 2009. Contribution of root and rhizosphere respiration to the annual variation of carbon balance of a boreal Scots pine forest. Biogeosciences 6:6179-6203.

Küçük, C., and Kıvanç, M. 2003. Isolation of Trichoderma spp. and determination of their antifungal, biochemical and physiological features. Turk. J. Biol. 27: 247-253.

Lamanceau, P., Bakker, P. A. H. M., Jan de Kogel, W., Alabouvette, C., and Schippers, B. 1993. Antagonistic effect of nonpathogenic Fusarium oxysporum Fo47 and psuedobactin 358 upon pathogenic Fusarium oxysporum f. sp. dianthi. Appl. Environ. Microbiol. 59:74-82.

Larkin, R. P., and Griffin, T. S. 2007. Control of soilborne potato diseases using Brassica green manures. Crop Prot. 26:1067-1077.

Larkin, R. P., Hopkins, D. L., and Martin, F. N. 1993a. Ecology of Fusarium oxysporum f. sp. niveum in soils suppressive and conducive to Fusarium wilt of watermelon. Phytopathology 83:1105-1116.

Larkin, R. P., Hopkins, D. L., and Martin, F. N. 1993b. Effect of successive watermelon plantings on Fusarium oxysporum and other microorganisms in soils suppressive and conducive to Fusarium wilt of watermelon. Phytopathology 83:1097-1105.

Larkin, R. P., Hopkins, D. L., and Martin, F. N. 1996. Suppression of Fusarium wilt of watermelon by nonpathogenic Fusarium oxysporum and other microorganisms recovered from a disease-suppressive soil. Phytopathology 86:812-819.

Leupold, U. 1970. Genetic methods for Schizosaccharomyces pombe. Methods Cell Biol. 4:169-177.

Lewis, J. A., and Papavizas, G. C. 1977. Effect of plant residues on chlamydosphore germination of Fusarium solani f. sp. phaseoli and on Fusarium root rot of bean. Phytopathology 67:925-929.

Lin, Y.-H., Chen, K.-S., Chang, J.-Y., Wan, Y.-L., Hsu, C.-C., Huang, J.-W., and Chang, P.-F. L. 2010. Development of the molecular methods for rapid detection and differentiation of Fusarium oxysporum and F. oxysporum $\mathrm{f}$. sp. niveum in Taiwan. New Biotechnol. 27:409-418.

Ling, G., Huang, Q., Guo, S., and Shen, Q. 2011. Paenibacillus polymyxa SQR-21 systematically affects root exudates of watermelon to decrease the conidial germination of Fusarium oxysporum f. sp. niveum. Plant Soil 341:485-493.

Littell, R. C., Henry, P. R., and Ammerman, C. B. 1998. Statistical analysis of repeated measures data using SAS procedures. J. Anim. Sci. 76:1216-1231.
Lucier, G., and Biing-Hwan, L. 2001. Factors affecting watermelon consumption in the United States. Pages 23-29 in: Vegetables and Specialties Situation and Outlook 287. United States Department of Agriculture Economic Research Service, Washington, DC.

Martínez-Medina, A., Pascual, J. A., Lloret, E., and Roldán, A. 2009. Interactions between arbuscular mycorrhizal fungi and Trichoderma harzianum and their effects on Fusarium wilt in melon plants grown in seedling nurseries. J. Sci. Food Agric. 89:1843-1850

Matsubara, Y., Ohba, N., and Fukui, H. 2001. Effect of arbuscular mycorrhizal fungus infection on the incidence of Fusarium root rot in asparagus seedlings. Jpn. Soc. Hortic. Sci. 70:202-206.

McCann, I., Kee, E., Adkins, J., Ernest, E., and Ernest, J. 2007. Effect of irrigation rate on yield of drip-irrigated seedless watermelon in a humid region. Sci. Hortic. (Amsterdam) 113:155-161.

Miller, D. E., and Burke, D. W. 1980. Resistance to bean root rot may be overcome by adverse soil conditions. Pages 67-68 in: Natl. Dry Bean Res. Conf. Annu. Rep.

Montalba, R., Arrigada, C., Alvear, M., and Zúniga, G. E. 2010. Effects of conventional and organic nitrogen fertilizers on soil microbial activity, mycorrhizal colonization, leaf antioxidant content, and Fusarium wilt in highbush blueberry (Vaccinium corymbosum L.). Sci. Hortic. (Amsterdam) 125:775-778

Morton, J. 2003. Staining of mycorrhizal roots. Online publication. International Culture Collection of (Vesicular) Arbuscular Mycorrhizae. http://invam.wvu. edu/methods/mycorrhizae/staining-roots

Netzer, D. 1976. Physiological races and soil population level of Fusarium wilt of watermelon. Phytoparasitica 4:131-136.

Newsham, K. K., Fitter, A. H., and Watkinson, A. R. 1995. Arbuscular mycorrhiza protect an annual grass from root pathogenic fungi in the field. J. Ecol. 83: 991-1000.

Njeru, E. M., Avio, L., Sbrana, C., Turrini, A., Bocci, G., Barberi, P., and Giovannetti, M. 2014. First evidence for a major cover crop effect on arbuscular mycorrhizal fungi and organic maize growth. Agron. Sustain. Dev. 34:841-848.

Ren, L., Zhang, N., Wu, P., Hup, H., Xu, G., and Wu, G. 2015. Arbuscular mycorrhizal colonization alleviates Fusarium wilt in watermelon and modulates the composition of root exudates. Plant Growth Regul. 77: $77-85$

Roberts, K. J., and Anderson, R. C. 2001. Effect of garlic mustard [Alliaria petiolata (Beib. Cavara \& Grande)] extracts on plants and arbuscular mycorrhizal (AM) fungi. Am. Midl. Nat. 146:146-152.

Rojo, F. G., Reynoso, M. M., Ferez, M., Chulze, S. N., and Torres, A. M. 2007 Biological control by Trichoderma species of Fusarium solani causing peanut brown root rot under field conditions. Crop Prot. 26:549-555.

Rutto, K. L., Mizutani, F., Moon, D. G., Cho, Y. S., and Kadoya, K. 2003 Seasonal fluctuations in mycorrhizal spore populations and infection rates of vineyard soils planted with five legume cover crops. J. Jpn. Soc. Hortic. Sci. 72:262-267.

Scheffknecht, S., Mammerler, R., Steinkellner, S., and Vierheilg, H. 2006. Root exudates of mycorrhizal tomato plants exhibit a different effect on microconidia germination of Fusarium oxysporum f. sp. lycopersici than root exudates from non-mycorrhizal tomato plants. Mycorrhiza 16: 365-370.

Schreiner, R. P., and Koide, R. T. 1993. Mustards, mustard oils, and mycorrhizas New Phytol. 123:107-113.

Sivan, A., and Chet, I. 1989. The role of competition between Trichoderma harzianum and Fusarium oxysporum on rhizosphere colonization. Phytopathology 79:198-203.

Smolinska, U., Morra, M. J., Knudsen, G. R., and James, R. L. 2003. Isothiocyanates produced by Brassicaceae species as inhibitors of Fusarium oxysporum. Plant Dis. 87:407-412.

Tobar, R. M., Azcon, R., and Barea, J. M. 1994. The improvement of plant N acquisition from an ammonium-treated, drought-stressed soil by the fungal symbiont in arbuscular mycorhizae. Mycorrhiza 4:105-108.

Tokala, R. K., Strap, J. L., Jung, C. M., Crawford, D. L., Salove, M. H., Deobald, L. A., Bailey, J. F., and Morra, M. J. 2002. Novel plant-microbe rhizosphere interaction involving Streptomyces lydicus WYEC108 and the pea plant (Pisum sativum). Appl. Environ. Microbiol. 68:2161-2171.

Tomaso-Peterson, M., and Perry, D. H. 2007. The role of biofungicides and organic fertilizer in the management of dollar spot in Bermuda grass. Online publication. Appl. Turfgrass Sci. 4. doi:10.1094/ATS-2007-0911-01-RS

Tsuneo, N. 1991. Diversity of root fungal floras: Its implications for soil-borne diseases and crop growth. Jpn. Agric. Res. Q. 25:6-11.

van Os, G. J., and van Ginkel, J. H. 2001. Suppression of Pythium root rot in bulbous Iris in relation to biomass and activity of the soil microflora. Soil Biol. Biochem. 33:1447-1454.

Weller, D. M., Raajimakers, J.-M., McSpadden Gardener, B. B., and Thomashow, L. S. 2002. Microbial populations responsible for specific soil suppressiveness to plant pathogens. Phytopathology 40:309-348.

Wu, H.-S., Yang, X.-N., Fan, J.-Q., Miao, W.-G., Ling, N., Xu, Y.-C., Huang, Q.-W., and Shen, Q. 2009. Suppression of Fusarium wilt of watermelon by a bio-organic fertilizer containing combinations of antagonistic microorganisms. BioControl 54:287-300. 
Yang, X., Chen, L., Yong, X., and Shen, Q. 2011. Formulations can affect rhizosphere colonization and biocontrol efficiency of Trichoderma harzianum SQR-T037 against Fusarium wilt of cucumbers. Biol. Fertil. Soils 47:239-248.

Yuan, M. W., and Crawford, D. L. 1995. Characterization of Streptomyces lydicus WYEC108 as a potential biocontrol agent against fungal root and seed rots. Appl. Environ. Microbiol. 61:3119-3128.

Zhou, X. G., and Everts, K. L. 2003. Races and inoculum density of Fusarium oxysporum f. sp. niveum in commercial watermelon fields in Maryland and Delaware. Plant Dis. 87:692-698.

Zhou, X. G., and Everts, K. L. 2004. Suppression of Fusarium wilt of watermelon by soil amendment with hairy vetch. Plant Dis. 88:1357-1365.
Zhou, X. G., and Everts, K. L. 2006. Suppression of Fusarium wilt of watermelon enhanced by hairy vetch green manure and partial cultivar resistance. Online publication. Plant Health Prog. doi:10.1094/PHP-2006-0405-01-RS

Zhou, X. G., and Everts, K. L. 2007. Effects of host resistance and inoculum density on the suppression of Fusarium wilt of watermelon induced by hairy vetch. Plant Dis. 91:92-96.

Zhou, X. G., Everts, K. L., and Armentrout, D. K. 2002. Hairy vetch and urea soil amendments: A novel strategy for management of Fusarium wilt of watermelon, 2002. Biological and Cultural Tests 18:V006. Online publication. doi:10.1094/BC17.

Zitter, T. A., Hopkins, D. L., and Thomas, C. E. 1996. Compendium of Cucurbit Diseases. American Phytopathological Society, St. Paul, MN. 